\title{
Enterprise risk management and firm value within China's insurance industry
}

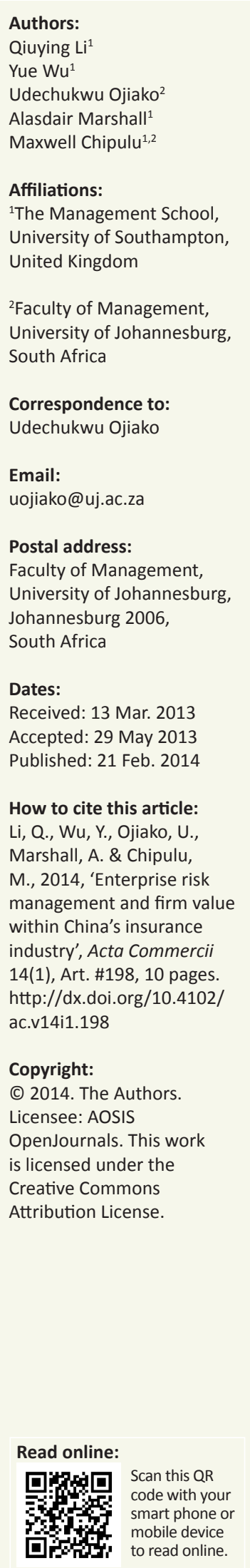

Orientation: The article discusses the relationship between enterprise risk management $(\mathrm{ERM})$ and firm value.

Research purpose: The purpose of the study is to empirically examine the relationship between ERM and firm value. The study is undertaken within the context of the Chinese insurance industry.

Motivation for the study: Recent attempts to link ERM with firm value have been undertaken primarily in the USA and Europe and have produced ambiguous and inconclusive findings.

Research design, approach and method: Data was obtained from the China Insurance Regulatory Commission, a government body responsible for regulating insurance products and services in China. The data sample consisted of 135 insurance companies operating in China (in 2010). Regression modelling is employed to analyse the data.

Main findings: The results show the relationship between ERM and firm value at first appears statistically significant within a Pearson correlation matrix but then falls below statistical significance on closer scrutiny through regression analysis. Accordingly, it is recommended that insurers in China should not look to aggressive investment in ERM as a strategy for producing quick gains in firm value.

Practical/managerial implications: Risk managers should plan ERM development from a risk management maturity perspective, which equates the highest level of ERM development with ERM's capacity to improve firm resilience to the unknown and serve as a mechanism for strategic decision-making.

Contribution/value-add: The study employed return on equity as a proxy for firm value, utilising ordinary least squares regression modelling to test propositions of the relationships between variables.

\section{Introduction}

This article is concerned with enterprise risk management (ERM) and its relationship to firm value. Recent attempts to link the two (e.g. Hoyt \& Liebenberg 2011; McShane, Nair \& Rustambekov 2011) have been undertaken primarily in the USA and Europe. These have produced ambiguous and inconclusive findings. The main lesson learned has been that further studies such as the present one need to set ERM beside a range of further variables so that its links to firm value can emerge more clearly.

In China, ERM programmes are now becoming commonplace, especially within the fast-developing insurance industry. In 2009, the China Insurance Regulatory Commission (CIRC), which is charged by the government to regulate insurance products and services, announced guidelines for ERM implementation within the Chinese life insurance market. These announcements were followed in 2012 by the publication of a framework for assessing ERM implementation amongst insurers more generally. In view of the fact that the Chinese insurance industry currently stands at a crucial moment in its development, we deemed it appropriate for our study to explore how ERM can help the industry. Our article begins with a brief theoretical exploration intended to support our empirical research, which we undertook to ascertain whether there is an emerging statistical relationship between ERM and firm value within the Chinese insurance industry. In the conclusion we emphasise that although a weak statistical relationship seems to exist, which may strengthen in future years as systems of ERM increasingly have their mettle tested, what may matter far more at present are the often subtle and not easily measurable ways in which firms can benefit from ERM. In the long run, all such benefits ought to be reflected together in any statistical relationships that are found to exist between ERM and firm value. Yet now, as the Chinese insurance industry liberalises in its asset management activities and moves to attract more global investment capital against a backdrop of rapidly evolving and sometimes 
unpredictable CIRC regulation, what matters is to establish just how ERM can add value across the firm - and indeed beyond the boundaries of the firm. The answers to this question are potentially many, and they must be considered very carefully if investments in ERM aimed at adding firm value are to be targeted efficiently.

\section{Literature review}

\section{What is enterprise risk management?}

Enterprise risk management (ERM) is a risk management philosophy that emphasises a strategic and integrated approach to managing risk (Liebenberg \& Hoyt 2003) and the many uncertainties from which risks emerge (Baxter et al. 2012). As Pagach and Warr (2011) illustrate, the primary objective of ERM is sometimes considered to be to lower the chances of firms experiencing substantial negative cash flows. This is generally achieved by taking a holistic approach to risk management, which reduces the chance that a firm will experience multiple negative events in its operations simultaneously. This concern with holism is emphasised by theorists (Baxter et al. 2012; Hoyt \& Liebenberg 2011; Kaplan \& Mikes 2012; McShane et al. 2011) who differentiate ERM from 'silo-based' forms of corporate risk management. Whilst this view of ERM as a system that can help firms withstand the effects of multiple simultaneous losses (e.g. large claims bursts arising across multiple lines of insurance business arising from 'fundamental' risk events) clearly has value, it does arguably tend to suffer from an unhelpfully reductive view of risk as 'threat', which is the hallmark of new and relatively undeveloped systems of risk management.

Best practice guidance around the world has, for several years now, striven to overturn this reductionist understanding by insisting that risk management can usefully comprise the management of both threat and opportunity (Ward 2005:39). We see this idea reflected in representations of ERM emphasising its concern to align strategic and operational decision-making capabilities to firm 'risk appetite' (Nocco \& Stulz 2006). Recent guidance produced by the Institute of Risk Management (IRM) emphasises that risk appetite is an intrinsically complex concept whose meaning is likely to vary across organisations; yet, it possesses this core meaning:

Most animals, including human beings, have a 'fight or flight' response to risk. In humans this can be over-ruled by our cognitive processes. Our interpretation of risk appetite is that it represents a corporate vision of exactly the same instincts and cognitive processes. However, since these instincts are not 'hardwired' in our corporate 'nervous and sensory' systems we use risk management as a surrogate. (IRM 2011:15)

This rich 'corporations as individual persons' metaphor perhaps transports us faster to understanding ERM than does any other theoretical approach. On this view, risk information should flow through a system of ERM to the 'corporate brain' just as pleasure and gain signals flow through the human nervous system to the human brain. In both cases, the brain can then decide whether to discontinue or to do more or less of the activities that produce these signals. What matters about ERM here is that it is essentially a strategic tool used to vary the firm's direction and objectives as it moves through its forever-shifting risk environment and this is what makes it 'more than' a system of internal controls that operates against preselected and unvarying objectives. Hence, within fully fledged systems of ERM, strategic objective setting simply becomes part of the cyclical risk management process (COSO 2004).

As a holistic undertaking, drawing on all the organisation's resources to facilitate strategic change, ERM has sought to coordinate and by implication control (see Shleifer \& Vishny 1986), the entire risk management portfolio, covering diverse functions such as auditing, human resources management and information systems. Such coordinating activities aspire to produce understandings of interrelationships between all risks within the firm, and to categorise these effectively within risk registers to be used as touchstones for strategic decision-making. Some discussions of ERM (Barney 1991; Quon, Zeghal \& Maingot 2012; Schrand \& Unal 1998) view this coordinated overview of firm risk as a potential source of competitive advantage, particularly in uncertain market conditions. Where such coordinated overviews are achieved, and risk becomes visible holistically at 'portfolio level', problems of 'cross-cutting' risks can be addressed and the risks associated with an individual portfolio on being aggregated may become less than the total sum of the individual risks (Carter, Rogers \& Simkins 2006).

\section{Firm value}

Firm value is an economic measure of a firm's performance which reflects the worth of the entire business (Grossman \& Stiglitz 1977; Sarma \& Rao 1969). Firm value focuses on the entire capital structure of the firm, thus allowing for its use in undertaking comparisons between firms of different structures of capital (Quiry et al. 2011). Hence, on the assumption that maximizing firm value represents a viable objective of many firms (Sundaram \& Inkpen 2004), the effectiveness of an ERM initiative within a firm may be based on an assessment of its capability to raise firm value against market competition.

The ability of ERM to enhance firm value may also be explained by drawing upon theories of institutional ownership that seek to articulate the relationship between firm performance and the structure of its ownerships. More recently articulated by scholars such as Chung and Zhang (2011) and Cheng, Elyasiani and Jia (2011), the theory of institutional ownership posits an inverse relationship between the level of stability or diffuseness of firm ownership and its performance. Expanded to risk taking, Cheng et al. found that stable institutional ownership was often associated with lower risktaking. Such findings become particularly important from a Chinese insurer perspective when we consider the outlook for increasing volatility in patterns of ownership over the next few years. The thrust of new CIRC regulation throughout 2012 has been to encourage private capital investment (the 15 June Implementation Opinions directive) whilst curbing the powers 
of controlling shareholders (the 01 October Administrative Measures on Controlling Shareholders of Insurers directive). We posit, based on earlier studies by Shleifer and Vishny (1986), that firm ownership remains an important element in management control (and, by implication, coordination) and so it becomes important to consider how changing patterns of ownership may impact the risk coordination activities we referred to in the previous section.

Generally, the expectation is that firms in financial service industries are more likely to implement ERM (Beasley, Clune \& Hermanson 2005; Beasley, Pagach \& Warr 2008) and subsequently increase corporate governance and market efficiency due to increased oversight of managerial risktaking (Beasley et al. 2005, 2008; Hoyt \& Liebenberg 2011). However, the precise nature of the relationship between ERM and firm value still remains inconclusive. For example, whilst Hoyt and Liebenberg (2011) suggest a correlation between ERM and firm value (defined from the perspective of improvements to firm efficiency), other scholars such as Beasley et al. (2008) only found such relationships to exist in firms engaged in the financial services industry. McShane et al. (2011) found that ERM and firm value are positively related in firms with low or adequate ERM ratings. On the other hand, they found no significant evidence of this positive relationship in firms with strong or excellent ERM ratings. Baxter et al. (2012) produced similar findings. Hoyt, Moore and Liebenberg (2006) and Gordon, Loeb and Tseng (2009) found ERM to have a positive impact on firm value; however, according to Gordon et al., the effects varied with firm size and complexity. A clearer cut finding is that of Hoyt et al. who found in a study of 125 publicly traded insurance firms in the United States that accrued ERM premium on firm value was approximately $17 \%$ of firm value. Taking stock of these mixed findings, the first proposition is put forward:

PR1: There is a positive relationship between ERM and firm value.

We decided to employ further variables related to firm value (and in various ways to ERM) within our study to facilitate a richer analysis of how ERM stands beside other factors as a creator of firm value. Earlier studies by Arena, Arnaboldi and Azzone (2010) and Hoyt and Liebenberg (2011) suggest that control represents a critical antecedent of enterprise risk management. Within the context of ERM, 'control' is a means of ensuring that firm value is created by enhancing the firm's capability in managing outcomes that are unexpected (Turner \& Makhija 2006). Thus, whilst firms may adopt ERM in order to ensure that threats and opportunities are identified and prioritised, the notion of 'control' covers assurance processes that grant some relatively impartial audit insight into ERM effectiveness.

Another important variable seen to impact on the relationship between ERM and firm value is firm size. This variable is used often in industrial economics literatures (Rahaman 2011), but its importance as a differentiator between firms with ERM programmes is becoming clear from the recent turn in ERM survey literature to focus on preferences for 'centralised' versus 'decentralised' systems of ERM within larger firms. Each approach is viewed by risk managers as having strengths and weaknesses for coping with the interrelated challenges of managerial control, oversight and strategic agility that matter for larger firms in particular (Deloitte 2012:5). Larger insurance companies obviously enjoy greater market power. Their greater underwriting capacity also allows them to retain more of the lucrative risks that would otherwise be transferred to reinsurance markets, and to grow their catastrophe and claims equalisations reserves as a precaution against large claims bursts; furthermore, their greater capacity for diversification grants them more leeway to vary resources across their lines of business to help them survive the vicissitudes of the various insurance cycles that turn differently for each line. Hence, it is no surprise that Liebenberg and Sommer (2008) found that larger insurance companies generally achieved higher returns on equity (ROE). Similarly, McShane and Cox (2009) found that larger life insurance firms had lower risk of bankruptcy. Following earlier studies by Beasley et al. (2008) and Hoyt and Liebenberg (2011), this study proposes the natural logarithm of book value of equity as a proxy for firm size, and therefore presents the second proposition:

PR2: There is a positive relationship between firm size and firm value.

Leverage is a further important firm variable; it refers to the extent of taking debt to acquire additional assets (Cheng, Liu \& Chien 2010; Pagach \& Warr 2011). Firms utilise debt to finance their businesses because this can reduce investments of free cash flow into suboptimal projects by self-interested managers (Jensen 1986). Also, taking on debt can lower a firm's tax burden (MacKie-Mason 1990). That is to say, financial leverage can increase firm value. Moreover, at higher levels of firm leverage lenders may become increasingly likely to insist that firms develop ERM (and by the same token corporate governance and risk management more generally) to help de-risk their investments. Lenders are likely to grow particularly concerned when a firm's debt becomes considerably higher than its assets. In such cases the excessive leverage will increase the probability of financial distress, thus leading the firm towards bankruptcy (Myers 1977). Remaining mindful of these issues around leverage, this study uses book value of liability divided by book value of equity as a proxy for leverage (Hoyt \& Liebenberg 2011; Tahir \& Razali 2011), and proposes the third proposition:

PR3: There is a positive relationship between leverage and firm value.

Studies (e.g. Myers 1977) have also shown sales growth as being another variable that can impact firm value. ERM's influence, relative to that of sales growth, upon firm value is of interest in view of the fact that aggressive and unsustainable sales growth by financial institutions prior to the global financial crisis is popularly viewed as a cultural problem that systems of risk management failed to address. Nonetheless, this study proposes, based on earlier studies by Maury (2006) and 
King and Santor (2008), that sales growth is likely to have a positive relationship with firm performance, and therefore presents the fourth proposition:

PR4: There is a positive relationship between sales growth and firm value.

Another variable of interest is ownership, which has been shown in literature (see Thomsen \& Pedersen 1996), to be associated with two dimensions of meaning. The first one is the concentration ownership, which focuses on the majority ownership of a firm's shares. Chen, Blenman and Chen (2008) found in their empirical study that institutional ownership is positively related to firm value. The other dimension is the legal status that regulates the ownership.

Some correlation between firm ownership and firm value appears to exist (Chen 2013; Pant \& Pattanayak 2007). Particularly relevant to our study is Wei, Xie and Zhang's (2005) exploration of the relationship between firm ownership and firm value in China. In their study spanning between 1991 and 2001, Wei et al. examined over 5000 firms, finding that those with the state as a majority stake-owner generally exhibited lower value whilst those with majority or total foreign ownership exhibited positive firm value. To control for the differences, this study uses a dummy variable to differentiate insurers with Chinese ownership from those with joint and foreign ownership, and proposes:

PR5: There is a positive relationship between joint or foreign ownership and firm value.

We also considered that the greater volatility of general as opposed to life insurance entails that ERM may play more significant value protective or creation roles for general insurers than for life insurers. In other words, at least for firms where ERM has made a contribution to firm value, we may well find general rather than life insurance clustering around these cases. To allow such effects to emerge from the analysis, a dummy variable was entered into the mix proposing that:

PR6: There is a negative relationship between life insurer and firm value.

In summary, all of the ambiguity arising from the extant literature linking ERM to firm value provides our rationale for undertaking the present study. Our research now undertook to explore this link with reference to a good range of variables, each of which were considered to perhaps play important and possibly sometimes subtly interrelated roles in the creation of firm value.

\section{Research methodology Measuring firm value}

Although associated with a number of limitations (see Dybvig \& Warachka 2012), it is common practice for scholars (e.g. Smirlock, Gilligan \& Marshall 1984; Smithson \& Simkins 2005; Wernerfelt \& Montgomery 1988) to employ Tobin's $\mathrm{Q}$ (Tobin 1969) as a proxy for firm value. Tobin's $Q$ is a ratio that compares a firm's market value of assets to their replacement cost. That is to say, Tobin's $Q$ can only be used for publicly traded firms, because it requires the assets' value in the market. However, this present study focuses on the whole of China's insurance industry, in which the majority of insurers are unlisted firms. Thus instead return on equity (ROE), which refers to the return on portfolios, is employed. Studies by Wang (2013), for example, suggest that under linear homogeneity assumptions, there is a direct correlation between firm value (measured as the performance of a new investment portfolio) and ROE. Based on this, ROE has been employed by earlier scholars such as Chen et al. (2008) and Nieh, Yau and Liu (2008) as a measure of firm value.

\section{Framework for data analysis}

To test the propositions we employed ordinary least squares (OLS) regression modelling, a technique frequently employed in studies focused on testing relationships between variables. Ordinary least squares regression modelling has been employed in a number of studies, such as Beasley et al. (2008) and Gordon et al. (2009), which have sought to examine determinant factor effect on firm value.

In statistics, OLS regression is utilised to estimate unknown parameters within a linear regression model (Balestra 1970; Haggstrom 1983). This method involves minimising the sum of squared residuals, in other words the vertical distance between the actual and estimated positions of the dependent variable (Stone \& Brooks 1990), with the resultant estimator being expressed using a simple mathematical formula (Shao 1990). Based on the variables and proposed relationships articulated in the previous chapter, the following regression model is proposed for testing the proposed relationships between ERM and firm value:

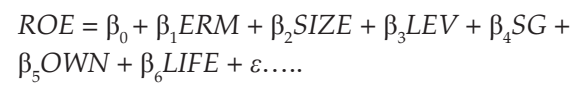

Where:

$R O E$ is the proxy for firm value, defined as net income divided by book value of equity.

$E R M$ is a dummy variable, set equal to 1 for insurers with ERM, and 0 otherwise. The expected sign of ERM is positive.

SIZE is the measure of firm size, defined as the natural logarithm of book value of equity. The expected sign of SIZE is positive.

$L E V$ is the measure of leverage, defined as book value of liability divided by book value of equity. The expected sign of LEV is positive.

$S G$ is the proxy for growth opportunities; it is sales growth, defined as the difference between sales of 2010 and sales of 2009 divided by sales of 2009. The expected sign of SG is positive.

OWN is a dummy variable, with the value of 1 for Chineseowned insurers, and 0 otherwise. The expected sign of $\mathrm{OWN}$ is negative.

LIFE is a dummy variable, which is assigned 1 for life insurance companies and 0 otherwise. The expected sign of LIFE is negative.

$\varepsilon$ is the error item, also known as the residual. 
In the regression model (shown in Equation 1), $R O E$ is a dependent variable, whilst ERM is an independent variable. The remaining independent variables are control variables, which are employed to control the association with firm value (and thus help to explain the relationship between ERM and firm value). The data was obtained from CIRC's records. Data analysis involved running the linear regression analysis function in SPSS.

\section{Sample and descriptive statistics}

The initial sample was drawn from the entire population of insurers operating in China in 2010. This comprised 135 insurance companies (obtained from CIRC's records). In terms of the datasets, we focused on data showing 'sales in 2009', 'book value of liability', 'book value of equity', 'sales in 2010 ', 'net income', 'firm deals in life insurance products' and 'firm ownership is Chinese-dominant'. Of the 135 firms listed on CIRC's database, 16 were eliminated because of missing data, thus leaving the final sample comprising 119 insurance firms.

According to Tabachnick and Fidell (2006), to test for individual regression coefficients, the sample size should be larger than 103 plus the number of independent variables, whilst to undertake $R$-square tests, the sample size should be no less than 50 plus eight times the number of independent variables. These therefore imply that a sample size of 119 insurers employed in this study is reliable.

A breakdown of the firms shows 55 being life insurers and 64 being non-life insurers. In terms of ownership, 66 were wholly Chinese-owned firms whilst the remaining 53 were either foreign owned or jointly owned with foreign firms. Twenty-five of the firms indicated wholesale adoption of ERM. Table 1 shows the mean and standard deviation for each variable used in this study.

TABLE 1: Mean and standard deviation for each variable.

\begin{tabular}{llll}
\hline Variable description & $\begin{array}{l}\text { Variable } \\
\text { name }\end{array}$ & Mean & $\begin{array}{l}\text { Standard } \\
\text { deviation }\end{array}$ \\
\hline Firm value & ROE & -0.00005 & 0.26608 \\
Enterprise risk management & ERM & 0.21008 & 0.40909 \\
Firm size & SIZE & 6.98058 & 1.60523 \\
Leverage & LEV & 6.29303 & 7.54453 \\
Sales growth & SG & 1.25755 & 3.54942 \\
Chinese ownership & OWN & 0.54462 & 0.49911 \\
Life insurance & LIFE & 0.46218 & 0.50068 \\
\hline
\end{tabular}

$N=119$.
The correlation matrix shown in Table 2 gives an overview of the bivariate relationships between variables. The correlations can, heeding earlier work by Tabachnick and Fidell (2006), be perceived as independent from the multivariable regression model. It can be observed from the $r$ matrix that ERM and three control variables are associated with firm value (ROE), although the correlations are weak. Also, the correlations between ERM and other independent variables are not large $(\leq 0.7)$, thus indicating that the problem of selectivity bias may not necessarily be of major concern. Moreover, as no variables show strong correlations, all are retained during OLS regression modelling for further analysis.

In Table 3, we show the summary of independent variables with proposed effects on ROE. The independent variable $R O E$ is the proxy for firm value.

Table 4 represents the assessment of the regression model (equation 1) adopted in this study. For multivariable regression, adjusted $R$-square should be more reliable than $R$-square, since the former adjusted the number of independent variables and sample size (see Tabachnick \& Fidell 2006). This model's adjusted $R$-square is $0.23^{1}$, implying that a $23 \%$ variance in $R O E$ is explainable by independent variables within the model. Additionally, the significance level of $F$ value being less than $1 \%$ confirms that the model is statistically significant. The Durbin-Watson statistic (Durbin \& Watson 1950, 1951) is employed to test the autocorrelation of residuals. The rationale for this test is that if autocorrelation exists, the regression model will not be applicable. With the numbers of insurers and independent variables, referring to the critical values for the Durbin-Watson test, Savin and White (1997) found that a Durbin-Watson value of 1.963 indicates the independence of residuals. Therefore, the analysis of adjusted $R$-square, significance of $F$ and DurbinWatson statistic confirms that the regression model's goodness-of-fit is acceptable.

\section{Coefficients, correlations and collinearity statistics}

Each coefficient (denoted by the $\beta$ values, as shown in Table 5) represents the extent to which a dependent variable will

1.In our calculations, we acknowledge that the $R$-square value is low but argue that this means the independent variables do substantively influence the variance of the dependent. We took this position because we did not come across any evidence, theoretical or empirical, to indicate that any important variables were missing from the model.

TABLE 2: Pearson correlation matrix.

\begin{tabular}{lllllll}
\hline Variable name & ROE & ERM & SIZE & LEV & SG & LWN \\
\hline ROE & 1.000 & - & - & - & - & - \\
ERM & $0.245^{* *}$ & 1.000 & - & - & - & - \\
SIZE & $0.355^{* *}$ & $0.503^{* *}$ & 1.000 & - & - & - \\
LEV & $0.365^{* *}$ & $0.190^{*}$ & $0.247^{* *}$ & 1.000 & - & - \\
SG & -0.113 & -0.108 & -0.069 & $-0.185^{*}$ & 1.000 & - \\
OWN & $0.253^{* *}$ & $0.213^{* *}$ & $0.532^{* *}$ & $0.182^{*}$ & 0.057 & - \\
LIFE & -0.141 & -0.106 & 0.066 & $0.271^{* *}$ & -0.079 & - \\
\hline
\end{tabular}

ERM, Enterprise risk management; LEV, Leverage; LIFE, Life insurer; OWN, Chinese ownership; ROE, Return on equity; SG, Sales growth; SIZE, Firm size.

*, Significance level of $5 \%$.

***, Significance level of $1 \%$. 
change following the changes of an independent variable whilst other independent variables are held constant. For example, the $\beta$ of SIZE is 0.046 , which implies ROE is expected to increase by 0.046 if SIZE increases one unit and other variables are held constant. The significance of coefficients is assessed by a $t$-test. It can be seen from the Table 5 that $E R M$ does not have statistically significant relationship with firm value $R O E$, and neither do sales growth $S G$ and Chinese ownership OWN. On the other hand, firm size SIZE and leverage $L E V$ are positively related to $R O E$ at $5 \%$ and $1 \%$ significance levels respectively, whilst life insurance LIFE is negatively related to $R O E$ at $1 \%$ significance level. Nevertheless, their relationships with $R O E$ are fairly weak.

In the correlations column, the bivariate correlations between ROE and independent variables were represented by zeroorder, whereas the partial shows the correlations after controlling for all other independent variables. It can be seen that $L E V$ has the highest positive correlation with $R O E$, whilst LIFE has the most negative correlation with ROE. Generally, collinearity tests are employed when testing whether at least one independent variable is highly correlated with a combination of other independent variables. As shown in Table 5, the variance inflationary factor (VIF) had no value lager than 10, which, based on earlier work by Belsley, Kuh and Welsch (1980), indicates that a multi-collinearity problem does not exist in this study.

TABLE 3: Summary of independent variables.

\begin{tabular}{|c|c|c|}
\hline $\begin{array}{l}\text { Independent } \\
\text { variable }\end{array}$ & $\begin{array}{l}\text { Proposed effect on } \\
\text { return on equity }\end{array}$ & Definition \\
\hline ERM & + & $\begin{array}{l}\text { Dummy variable: } 1 \text { = insurers with } \\
\text { enterprise risk management, } 0 \text { otherwise }\end{array}$ \\
\hline SIZE & + & Firm size = Ln (book value of equity) \\
\hline LEV & + & $\begin{array}{l}\text { Leverage = book value of liability / book } \\
\text { value of equity }\end{array}$ \\
\hline$S G$ & + & $\begin{array}{l}\text { Sales growth }=\text { (sales of } 2010 \text { - sales of } \\
2009) / \text { sales of } 2009\end{array}$ \\
\hline OWN & - & $\begin{array}{l}\text { Dummy variable: } 1 \text { = insurers with } \\
\text { Chinese ownership, } 0 \text { otherwise }\end{array}$ \\
\hline LIFE & - & $\begin{array}{l}\text { Dummy variable: } 1 \text { = life insurer, } 0 \\
\text { otherwise }\end{array}$ \\
\hline
\end{tabular}

TABLE 4: Model assessment.

\begin{tabular}{lllll}
\hline $\boldsymbol{R}$-square & $\begin{array}{l}\text { Adjusted } \\
\boldsymbol{R} \text {-square }\end{array}$ & $\boldsymbol{F}$ & Significance & $\begin{array}{l}\text { Durbin- } \\
\text { Watson }\end{array}$ \\
\hline 0.272 & 0.233 & 6.960 & $<0.001$ & 1.963 \\
\hline
\end{tabular}

Note: Dependent variable: ROE; predictors: (constant), LIFE, SIZE, SG, LEV, ERM, OWN.
In sum, from Figure 1a, the residuals are observed to be normally distributed. In the scatterplot graph (Figure 1b), there appears no discernable pattern, which indicates the homogeneity of variance and supports the linearity of variables, thus indicating that the validity of the data is high.

\section{Findings}

A review of the outcomes from the data analysis shows that in terms of the first proposition (PR1: There is a positive relationship between ERM and firm value), it can be found in the model assessment (Table 4) and table showing coefficients, correlations and collinearity statistics (Table 5) that ERM was positively correlated to firm value, although not significantly - and certainly not with sufficient magnitude to legitimate strong claims concerning ERM's potential to add value within China's insurance industry. This ambiguous finding for PR1 may be construed as in line with earlier studies. Previous literature (Gordon et al. 2009; Hoyt \& Liebenberg 2011; McShane et al. 2011; Tahir \& Razali 2011) appears to indicate two conflicting perceptions of ERM's ability to create value for firms. Stronger positive claims come from studies by Nocco and Stulz (2006), Shamieh (2007) and Zaccanti (2009). For example whilst Nocco and Stulz found ERM enhancing firm value through better risk-based allocation of resources, Shamieh saw ERM as being able to enhance firm value through all it does to achieve solvency regulation compliance. Counter claims of zero or negative impact on firm value come from studies such as Roll (1986) who draws attention to the high costs associated with ERM adoption. Furthermore, Lin, Wen and Yu (2012) argue that a major contributing factor to the failure of ERM adoption resides with managers underestimating costs associated with not only initiating, but also maintaining ERM initiatives.

Taking stock of these mixed views, we considered it inappropriate to read much into our weak statistical generalisations, and instead chose to rely heavily on more detailed findings emerging from OLS regression. A review of prior studies by Hoyt and Liebenberg (2011) suggested the possibility of employing the Heckman (1979) two-stage selection correction model (see Puhani 2000). Hoyt and Liebenberg employed this model to explore drivers for ERM, which involved employing a probit regression model to explain the relationships between ERM and its determinants prior to using an OLS regression model to then examine the effect of independent variables on firm value. However, in

TABLE 5: Coefficients, correlations and collinearity statistics.

\begin{tabular}{|c|c|c|c|c|c|c|c|c|c|}
\hline \multirow[t]{2}{*}{ Variable name } & \multicolumn{2}{|c|}{ Unstandardised Coefficients } & \multirow[t]{2}{*}{$t$} & \multirow[t]{2}{*}{ Significance } & \multicolumn{3}{|c|}{ Correlations } & \multicolumn{2}{|c|}{ Collinearity statistics } \\
\hline & B & Standard error & & & Zero-order & Partial & Part & Tolerance & $\begin{array}{l}\text { Variance inflationary } \\
\text { factor }\end{array}$ \\
\hline (Constant) & -0.332 & 0.111 & -3.005 & 0.003 & - & - & - & - & - \\
\hline ERM & 0.003 & 0.063 & 0.049 & 0.961 & 0.245 & 0.005 & 0.004 & 0.700 & 1.429 \\
\hline SIZE & 0.046 & 0.018 & 2.479 & 0.015 & 0.355 & 0.228 & 0.200 & 0.523 & 1.911 \\
\hline LEV & 0.013 & 0.003 & 3.999 & 0.000 & 0.365 & 0.353 & 0.322 & 0.819 & 1.220 \\
\hline SG & -0.004 & 0.006 & -0.579 & 0.564 & -0.113 & -0.055 & -0.047 & 0.947 & 1.056 \\
\hline OWN & 0.002 & 0.053 & 0.030 & 0.976 & 0.253 & 0.003 & 0.002 & 0.651 & 1.537 \\
\hline LIFE & -0.137 & 0.047 & -2.915 & 0.004 & -0.141 & -0.266 & -0.235 & 0.829 & 1.206 \\
\hline
\end{tabular}

Note: Dependent variable: ROE; predictors: (constant), LIFE, SIZE, SG, LEV, ERM, OWN. 

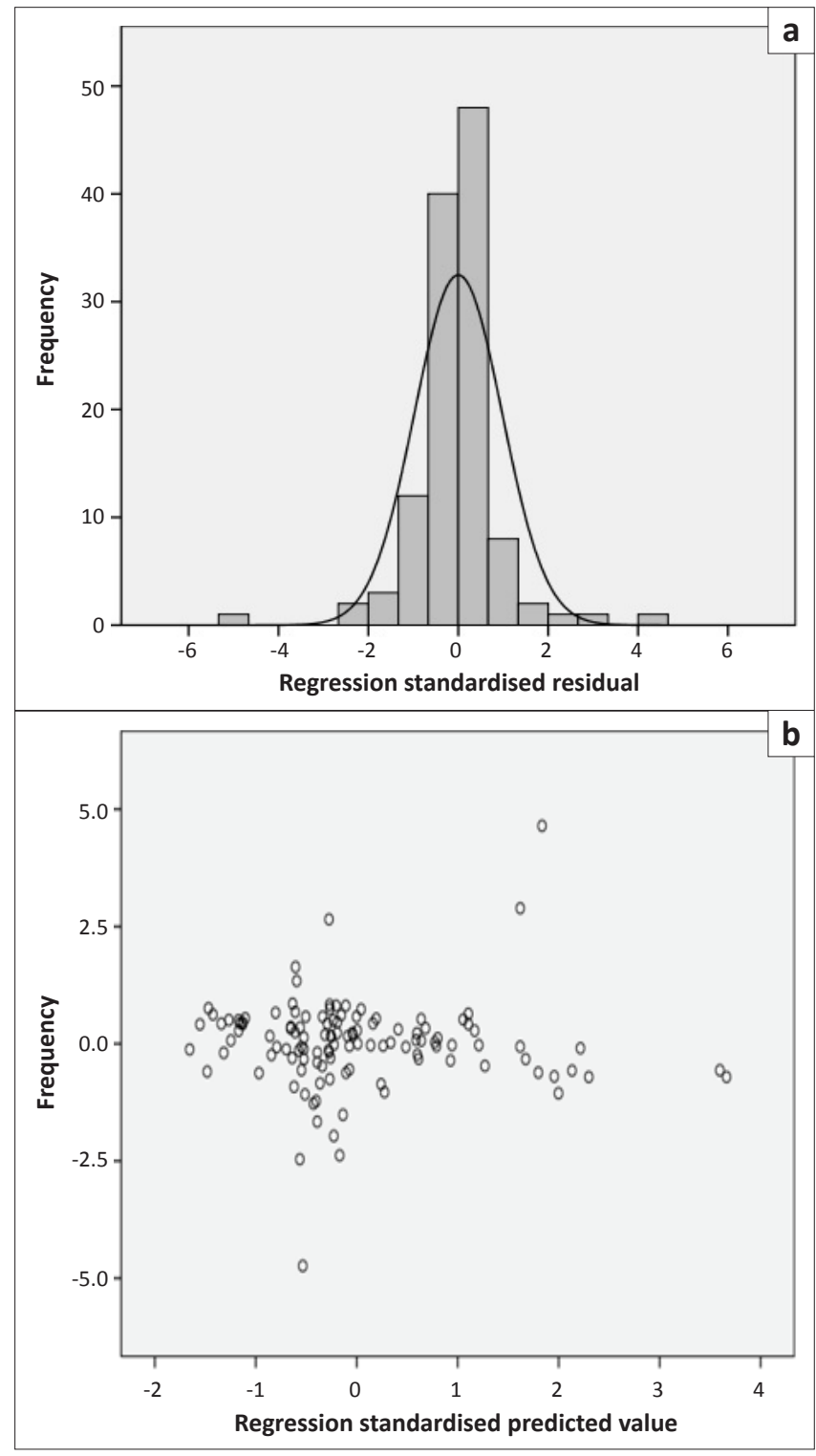

FIGURE 1: Normality, homogeneity and linearity: (a) Histogram and (b) scatterplot.

this study, considering that examining ERM's determinants was not a research objective, probit regression modelling was not conducted.

In terms of the second proposition (PR2: There is a positive relationship between firm size and firm value), the coefficient of SIZE in Table 5 shows firm size as being positively related to firm value at $5 \%$ significance level, thus confirming the second proposition. Our findings are in line with earlier studies. For example, Beasley et al. (2005) suggest that ERM adoption is largely determined by firm size. Further evidence of this effect can be found in Liebenberg and Sommer (2008) and McShane and Cox (2009). Based on our findings we can concur that larger insurance firms in China generally seem to obtain higher returns on equity.

In terms of the third proposition (PR3: There is a positive relationship between leverage and firm value), we found that the coefficient of $L E V$ was positive and statistically significant, thus implying a significantly positive leverage against firm value; hence the acceptance of the third proposition. This finding is in line with those of Cheng et al. (2010) and Pagach and Warr (2011). These findings help to clarify the context within which ERM becomes valuable for firms. As Pagach and Warr suggest, when firms become increasingly levered, they become increasingly likely to commission ERM programmes to deal with increased volatility in earnings and stock performance.

The fourth proposition of the study (PR4: There is a positive relationship between sales growth and firm value) was however rejected. Regression analysis showed that the coefficient of SG was not only negative but also insignificant. This finding was consistent with earlier studies, particularly McShane et al. (2011), who found a similar negative effect but at a significant level. These findings should remind us, perhaps, that for Chinese insurers as for many firms more generally more sales do not necessarily produce higher returns on firm equity. For insurers in particular, careful decisions often have to be taken to cap or wind down lines of business where profit margins are being squeezed or where insured risks are escalating. If systems of managerial incentives work well, then incentives to keep the sales engine fired up should reduce as underwriting capacity becomes exhausted and higher proportions of business must then be transferred to reinsurers. Careful regulation of sales growth may therefore sometimes serve as a proxy for the sort of wellgoverned, prudent insurance firm that is most likely to make ERM a success, and which is also more likely to create value for shareholders.

In terms of the fifth proposition (PR5: There is a positive relationship between Chinese ownership and firm value), it was observed that the coefficient of OWN was positive (but not significant), thus suggesting that neither Chinese nor foreign ownership of insurance firms seems to enhance firm value. On this basis, we rejected the fifth proposition.

Finally, for our sixth proposition (PR6: There is a negative relationship between life insurer and firm value), we observed a significant negative value for the coefficient of LIFE, which serves to underscore the likelihood that an important business context in which ERM can contribute to firm value is likely to be the - perhaps obvious - one in which ERM can help give insurers confidence to expose themselves to the more volatile and 'quick win' general insurance markets.

\section{Conclusion}

Noting that empirical studies testing value-added hypotheses suggesting a relationship between ERM and firm value remained largely scarce, our study sought to empirically examine the relationship between ERM and firm value. This examination was undertaken within the context of the Chinese insurance industry, leading to the presentation of six propositions to be tested:

PR1: There is a positive relationship between ERM and firm value. 
PR2: There is a positive relationship between firm size and firm value.

PR3: There is a positive relationship between leverage and firm value.

PR4: There is a positive relationship between sales growth and firm value.

PR5: There is a positive relationship between joint or foreign ownership and firm value.

PR6: There is a negative relationship between life insurer and firm value.

We employed return on equity (ROE) as a proxy for firm value, utilising ordinary least squares (OLS) regression modelling to test propositions of the relationships between variables. Data was obtained from the China Insurance Regulatory Commission (CIRC), a government body responsible for regulating insurance products and services in China. The data sample consisted of 135 insurance companies operating in China (in 2010). In all, our findings were mixed. For example, whilst the test of our first proposition (PR1) was inconclusive, in terms of the second (PR2), third (PR3) and sixth propositions (PR6), significant positive relationships were found. On the other hand, in the case of the fourth (PR4) and fifth propositions (PR5), the likelihood of a real link was rejected. The results of the study were mixed, initially showing the relationship between ERM and Chinese ownership as significant, but on further examination, the correlation became less significant.

A critical question that emerges from this study is therefore whether the adoption of ERM could increase the objectivity and transparency of Chinese firms to the extent that ERM begins to enhance firm value. This question is extremely pertinent because, as earlier cited, according to arguments put forward by scholars such as Barney (1991), Quon et al. (2012), Schrand and Unal (1998) and Shleifer and Vishny (1986), risk when managed at an enterprise level does have the potential to add value to firm operations. As earlier indicated, ERM emphasises a strategic perspective of managing risk. Noting that earlier scholars such as Coase (1937) had pointed out that transactions are generally placed within a firm when the cost of business is lower than the cost of placing such business activities outside, ERM will be able to facilitate the creation of firm value through its ability to enhance the organisation's ability to either reduce or eliminate lowerend activities within the firm that are associated with high transaction costs. The main underlying theory supporting such positioning is transaction cost economics (TCE; see Chiles \& McMackin 1996; Ghoshal \& Moran 1996; Klaes 2000), which utilises behavioural assumptions to predict how organisations make choices on their governance structures. The main ethos of TCE is that governance structures are primarily determined by an assessment of parties of asset specificity levels, how frequent different parties interact and the degree of risk surrounding such interactions. In effect, according to Grossman and Hart (1986:74), TCE posits that governance structures are a function of the attributes of transactions, therefore suggesting that ERM can create value by reducing the probability that a particular risk does impact adversely on the firm. Enterprise risk management can therefore enhance firm value to the extent that the adoption of ERM serves as a means of ensuring that firms do have sufficient internal control mechanisms that minimise their exposure to risk associated with engaging in innovative (and thereby risky) activities (see Marshall \& Ojiako 2010).

There are of course challenges to the adoption of ERM by Chinese insurance firms. In the first place, whilst the majority of the firms sampled (by the nature of their business) were expected to operate risk management units, information on their expertise and robustness (quality) of their risk management processes remained largely unknown. In fact, recognising that the concept of risk remains to an extent vague (Fischhoff, Watson \& Hope 1984; Hansson 1989, 1996), it remains to an extent possible that notions of ERM within the sample were diverse with different firms interpreting ERM differently and across a range of different organisational or competitive contexts. This situation provides an opportunity for future studies where extra care may be needed to first establish (perhaps via qualitative interviews) how potential respondents in a sample conceive the two concepts that formed the core of this study, 'value' and 'ERM', prior to sampling. Establishing respondent perception of the two concepts may also involve the utilisation of the analytic hierarchy process (AHP). In such scenarios, AHP is employed to examine and weight defining variables that are more closely associated with a specific target sample. The utilisation of OLS regression modelling to test relationships between variables also provides scholars with opportunities for future studies. More specifically, although the application of ROE and general regression modelling is a common practice in economic sciences research, most recent research shows a growing interest of researchers in implementation of complex approaches to such studies. As such, future studies may seek to employ the use of multidimensional methods of data analysis, such as analytic, artificial neural networks and other artificial intelligence methods for analysis, thus not only allowing for the simultaneous analysis of multiple measures of firm value and determinants that are likely to reflect the economic reality of Chinese insurance sector, but also addressing possible concerns relating to any doubts that direct implementation of Western-tested ERM systems can be successfully incorporated into Chinese managerial practices.

We therefore argue that a limitation within this study is that because the conceptualisation of 'value' and 'ERM' were preset and did not emergenaturally from the sample, the potential richness of specific cultural considerations of 'value' and 'ERM' were lost. Being that the study emphasised a Chinese context, possible studies in the future may be required to draw upon commonly employed firm value indexes that appears peculiar to emerging markets such as China or to extend the 'lessons learnt' to other emerging economies such as Brazil, South Africa, India and Nigeria in order to ensure that practical relevance to a wider management audience is maintained. 


\section{Acknowledgements Competing interests}

The authors declare that they have no financial or personal relationship(s) that may have inappropriately influenced them in writing this article.

\section{Authors' contributions}

Q.L. (University of Southampton), Y.W. (University of Southampton), U.O. (University of Johannesburg), A.M. (University of Southampton) and M.C. (University of Southampton and University of Johannesburg) all made equal conceptual contributions that led to the development of this article.

\section{References}

Arena, M., Arnaboldi, M. \& Azzone, G., 2010, 'The organizational dynamics of Enterprise Risk Management', Accounting, Organizations and Society 35(7), 659675. http://dx.doi.org/10.1016/j.aos.2010.07.003

Balestra, P., 1970, 'On the efficiency of ordinary least-squares in regression models', Journal of the American Statistical Association 65(331), 1330-1337. http://dx.doi. Journal of the American Statistical Associat
org/10.1080/01621459.1970.10481168

Barney, J., 1991, 'Firm resources and sustained competitive advantage', Journal of Management 17, 99-120. http://dx.doi.org/10.1177/014920639101700108

Baxter, R., Bedard, J., Hoitash, R. \& Yezegel, A., 2012, 'Enterprise risk management program quality: Determinants, value relevance, and the financial crisis', Contemporary Accounting Research, Forthcoming.

Beasley, M., Clune, R. \& Hermanson, D., 2005, 'Enterprise risk management: An empirical analysis of factors associated with the extent of implementation', Journal of Accounting and Public Policy 24(6), 521-531. http://dx.doi.org/10.1016/j. jaccpubpol.2005.10.001

Beasley, M., Pagach, D. \& Warr, R., 2008, 'Information conveyed in hiring announcements of senior executives overseeing enterprise-wide risk management processes', Journal of Accounting, Auditing \& Finance 23, 311-332.

Belsley, D., Kuh, E. \& Welsch, R., 1980, Regression Diagnostics, identifying influentia data and sources of collinearity, John Wiley \& Sons, Ltd, London. http://dx.doi. org/10.1002/0471725153

Carter, D., Rogers, D. \& Simkins, B., 2006, 'Does hedging affect firm value? Evidence from the US airline industry', Financial Management 35, 53-86. http://dx.do org/10.1111/j.1755-053X.2006.tb00131.x

Chen, J., Blenman, L. \& Chen, D., 2008, 'Does institutional ownership create values? The New Zealand case', Quarterly Journal of Finance and Accounting 47(4), 109124.

Chen, M., 2013, 'Adjustments in managerial ownership and changes in firm value', International Review of Economics \& Finance 25, 1-12. http://dx.doi. org/10.1016/j.iref.2012.04.008

Cheng, J., Elyasiani, E. \& Jia, J., 2011, 'Institutional ownership stability and risk taking: Evidence from the life-health insurance industry', Journal of Risk and Insurance 78(3), 609-641.

Cheng, Y., Liu, Y. \& Chien, C., 2010, 'Capital structure and firm value in China: A panel threshold regression analysis', African Journal of Business Management 4(12), 2500-2507.

Chiles, T. \& McMackin, J., 1996, 'Integrating variable risk preferences, trust, and transaction cost economics', Academy of Management Review 21(1), 73-99.

Chung, K. \& Zhang, H., 2011, 'Corporate governance and institutional ownership', Journal of Financial and Quantitative Analysis 46(1), 247-273. http://dx.doi. org/10.1017/S0022109010000682

Coase, R., 1937, 'The nature of the firm', Economica 4, 386-405. http://dx.doi org/10.1111/j.1468-0335.1937.tb00002.x

Committee of Sponsoring Organizations of the Treadway Commission (COSO), 2004 Executive Summary Enterprise Risk Management - Integrated Framework, AICPA, New York.

Deloitte, 2012, Aftershock: Adjusting to the new world of risk management, Deloitte LLP, London.

Durbin, J. \& Watson, G., 1950, 'Testing for serial correlation in least squares regression, I', Biometrika 37, 409-428.

Durbin, J. \& Watson, G., 1951, 'Testing for serial correlation in least squares regression, II', Biometrika 38, 159-179.

Dybvig, P. \& Warachka, M., 2012, Tobin's Q does not measure RM performance: Theory, empirics, and alternative measures, SSRN eLibrary, viewed 18 March 2013, from http://papers.ssrn.com/sol3/papers.cfm?abstract id=1562444
Fischhoff, B., Watson, S. \& Hope, C., 1984, 'Defining risk', Policy Sciences 17, 123-139. http://dx.doi.org/10.1007/BF00146924

Ghoshal, S. \& Moran, P., 1996, 'Bad for practice: A critique of the transaction cost theory', Academy of Management Review 21(1), 13-47.

Gordon, L., Loeb, M. \& Tseng, C., 2009, 'Enterprise risk management and firm performance: A contingency perspective', Journal of Accounting and Public Policy 28(4), 301-327. http://dx.doi.org/10.1016/j.jaccpubpol.2009.06.006

Grossman, S. \& Hart, O., 1986, 'The costs and benefits of ownership: A theory of vertical and lateral integration', Journal of Political Economy 94(4), 691-719. http://dx.doi.org/10.1086/261404

Grossman, S. \& Stiglitz, J., 1977, 'On value maximization and alternative objectives of the firm', Journal of Finance 32(2), 389-402. http://dx.doi. org/10.1111/j.1540-6261.1977.tb03278.x

Haggstrom, G., 1983, 'Logistic regression and discriminant analysis by ordinary least squares', Journal of Business \& Economic Statistics 1(3), 229-238.

Hansson, S., 1989, 'Dimensions of risk', Risk Analysis: An International Journal 9, 107-112.

Hansson, S., 1996, 'What is philosophy of risk?', Theoria 62, 169-186. http://dx.doi. org/10.1111/j.1755-2567.1996.tb00536.x

Heckman, J., 1979, 'Sample selection bias as a specification error', Econometrica 47(1), 153-161. http://dx.doi.org/10.2307/1912352

Hoyt, R. \& Liebenberg, A., 2011, 'The value of enterprise risk management', Journal of Risk and Insurance 78(4), 795-822. http://dx.doi.org/10.1111/j.15396975.2011.01413.x

Hoyt, R., Moore, D. \& Liebenberg, A., 2006, The value of enterprise risk management: Evidence from the US insurance industry, Terry College of Business, University of Georgia, viewed 14 August 2009, from http://www.soa.org/library/monographs/ other-monographs/2008/april/mono-2008-m-as08-1-hoyt.pdf

Institute of Risk Management, 2011, Risk Appetite \& Tolerance Guidance Paper, viewed 21 March 2013, from http://theirm.org/publications/risk_appetite.html

Jensen, M., 1986, 'Agency costs of free cash flow, corporate finance and takeover', American Economic Review 76, 323-329.

Kaplan, R. \& Mikes, A., 2012, 'Managing risks: A new framework', Harvard Business Review 90(6), 48-56.

King, M. \& Santor, E., 2008, 'Family values: Ownership structure, performance and capital structure of Canadian firms', Journal of Banking and Finance 32, 24232432. http://dx.doi.org/10.1016/j.jbankfin.2008.02.002

Klaes, M., 2000, 'The history of the concept of transaction costs: Neglected aspects', Journal of the History of Economic Thought 22(2), 191-216. http://dx.doi. org/10.1080/10427710050025411

Liebenberg, A. \& Hoyt, R., 2003, 'The determinants of enterprise risk management: Evidence from the appointment of chief risk officers', Risk Management and Insurance Review 6(1), 37-52. http://dx.doi.org/10.1111/1098-1616.00019

Liebenberg, A. \& Sommer, D., 2008, 'Effects of corporate diversification: Evidence from the property-liability insurance industry', Journal of Risk and Insurance 75 , from the property-liability insurance industry', Journal of Risk
893-919. http://dx.doi.org/10.1111/j.1539-6975.2008.00290.x

Lin, Y., Wen, M. \& Yu, J., 2012, 'Enterprise risk management: Strategic antecedents, risk integration and performance', North American Actuarial Journal 16(1), 1-28. http://dx.doi.org/10.1080/10920277.2012.10590630

MacKie-Mason, J., 1990, 'Do taxes affect corporate financing decisions?', Journal of Finance 45(5), 1471-1493. http://dx.doi.org/10.1111/j.1540-6261.1990. tb03724.x

Marshall, A \& Ojiako, G.U., 2010, 'From the myth of Prometheus to strategic resilience: Two cognitive paradigms linking risk and innovation', Prometheus 28(4), 343-360. http://dx.doi.org/10.1080/08109028.2010.539018

Maury, B., 2006, 'Family ownership and firm performance: Empirical evidence from Western European corporations', Journal of Corporate Finance 12, 321-341. http://dx.doi.org/10.1016/j.jcorpfin.2005.02.002

McShane, M. \& Cox, L., 2009, 'Issuance decisions and strategic focus: The case of long-term care insurance', Journal of Risk and Insurance 76, 87-108. http://dx.doi. org/10.1111/j.1539-6975.2009.01289.x

McShane, M., Nair, A. \& Rustambekov, E., 2011, 'Does Enterprise risk management increase firm value?', Journal of Accounting, Auditing \& Finance 26(4), 641-658. $\mathrm{http}: / / \mathrm{dx}$.doi.org/10.1177/0148558X11409160

Myers, S., 1977, 'The determinants of corporate borrowing', Journal of Financial Economics 5(2), 147-175. http://dx.doi.org/10.1016/0304-405X(77)90015-0

Nieh, C., Yau, H. \& Liu, W., 2008, 'Investigation of target capital structure for electronic listed firms in Taiwan', Emerging Markets Finance and Trade 44(4), 75-87. http:// dx.doi.org/10.2753/REE1540-496X440406

Nocco, B. \& Stulz, R., 2006, 'Enterprise risk management: Theory and practice', Journal of Applied Corporate Finance 18(4), 8-20. http://dx.doi.org/10.1111/j.17456622.2006.00106.x

Pagach, D. \& Warr, R., 2011, 'The characteristics of firms that hire chief risk officers', Journal of Risk and Insurance 78, 185-211. http://dx.doi.org/10.1111/j.15396975.2010.01378.x

Pant, M. \& Pattanayak, M., 2007, 'Insider ownership and firm value: Evidence from Indian corporate sector', Economic and Political Weekly 42(16), 1459-1467.

Puhani, P., 2000, 'The Heckman correction for sample selection and its critique', Journal of Economic Surveys 14(1), 53-68. http://dx.doi.org/10.1111/14676419.00104 
Quiry, P., Le Fur, Y., Salvi, A., Dallochio, M. \& Vernimmen, P., 2011, Corporate Finance: Theory and Practice, 3rd edn., John Wiley \& Sons, Ltd, London.

Quon, T., Zeghal, D. \& Maingot, M., 2012, 'Enterprise risk management and firm performance', Procedia-Social and Behavioral Sciences 62, 263-267. http:// dx.doi.org/10.1016/j.sbspro.2012.09.042

Rahaman, M., 2011, 'Access to financing and firm growth', Journal of Banking \& Finance 35(3), 709-723. http://dx.doi.org/10.1016/j.jbankfin.2010.09.005

Roll, R., 1986, 'The hubris hypothesis of corporate takeovers', Journal of Business 59(2), 197-216. http://dx.doi.org/10.1086/296325

Sarma, L. \& Rao, K., 1969, 'Leverage and the value of the firm', Journal of Finance 24(4), 673-677. http://dx.doi.org/10.1111/j.1540-6261.1969.tb00391.x

Savin, N. \& White, K., 1997, 'The Durbin-Watson test for serial correlation with extreme sample sizes or many regressors', Econometrica 45, 1989-1996. http:// dx.doi.org/10.2307/1914122

Schrand, C. \& Unal, H., 1998, 'Hedging and coordinated risk management: Evidence from thrift conversions', Journal of Finance 53, 979-1013. http://dx.doi. org/10.1111/0022-1082.00041

Shamieh, C., 2007, Implementing EC: Recent Experience. SOA/Tillinghast Insurance Seminar on Economic Capital, American International Group viewed 06 September 2009, from http://riskisopportunity.com/files/pdf/2007-chicagoshamieh.pdf

Shao, J., 1990, 'Ordinary and weighted least-squares estimators', Canadian Journal of Statistics 18(4), 327-336. http://dx.doi.org/10.2307/3315839

Shleifer, A. \& Vishny, R., 1986, 'Large shareholders and corporate control', Journal of Political Economy 94, 461-448. http://dx.doi.org/10.1086/261385

Smirlock, M., Gilligan, T. \& Marshall, W., 1984, 'Tobin's Q and the structureperformance relationship', American Economic Review 74(5), 1051-1060.

Smithson, C. \& Simkins, B., 2005, 'Does risk management add value? A survey of the evidence', Journal of Applied Corporate Finance 17(3), 8-17. http://dx.doi. org/10.1111/j.1745-6622.2005.00042.x
Stone, M. \& Brooks, R., 1990, 'Continuum regression: Cross-validated sequentially constructed prediction embracing ordinary least squares, partial least squares and principal components regression', Journal of the Royal Statistical Society. Series B (Methodological) 52(2), 237-269.

Sundaram, A. \& Inkpen, A., 2004, 'The corporate objective revisited', Organization Science 15(3), 350-363. http://dx.doi.org/10.1287/orsc.1040.0068

Tabachnick, B. \& Fidell, L., 2006, Using Multivariate Statistics, 5th edn., Allyn \& Bacon, Boston.

Tahir, I. \& Razali, A., 2011, 'The Relationship between enterprise risk management (ERM) and firm value: Evidence From Malaysian public listed companies', International Journal of Economics and Management Sciences 1(2), 32-41.

Thomsen, S. \& Pedersen, T., 1996, 'Nationality and ownership structures: The 100 largest companies in six European nations', Management International Review 36(2), 149-166.

Tobin, J., 1969, 'A general equilibrium approach to monetary theory', Journal of Money Credit and Banking 1(1), 15-29. http://dx.doi.org/10.2307/1991374

Turner, K. \& Makhija, M., 2006, 'The role of organizational controls in managing knowledge', Academy of Management Review 31(1), 197-217. http://dx.doi. org/10.5465/AMR.2006.19379631

Wang, Z., 2013, 'Do the investment and return-on-equity factors proxy for economic risks?', Financial Management 42(1), 183-209. http://dx.doi.org/10.1111/j.1755053X.2012.01212.x

Ward, S., 2005, Risk Management Organisation and Context, Witherby \& Co. Ltd, London.

Wei, Z., Xie, F. \& Zhang, S., 2005, 'Ownership structure and firm value in China's privatized firms: 1991-2001', Journal of Financial and Quantitative Analysis 40(1), 87-108. http://dx.doi.org/10.1017/S0022109000001757

Wernerfelt, B. \& Montgomery, C., 1988, 'Tobin's Q and the importance of focus in firm performance', American Economic Review 78(1), 246-250.

Zaccanti, B., 2009, 'ERM bolsters evolution of insurance RM', National Underwriter Property \& Casualty Risk \& Benefits Management 113(15), 29-35. 